\title{
Empirical Analysis on International Competitiveness of China's Service Trade on the Basis of Diamond Model
}

\author{
Dengxin Dong \\ School of Literature, Law and Economics \\ Wuhan University of Science and Technology \\ Wuhan, Hubei, China 430065
}

\author{
Qian Zhang \\ School of Literature, Law and Economics \\ Wuhan University of Science and Technology \\ Wuhan, Hubei, China 430065
}

\begin{abstract}
Based on the Michael Porter Diamond Model, This article conducts empirical researches on factors influencing the international competitiveness of China in service trade. First, according to the data of $1985-2013$, it selects foreign direct investment (FDI), GDP per capita, service trade market openness, service trade development level and goods trade development level for empirical tests. Then it analyzes long term and short term factors influencing the international competitiveness of China in service trade through Cointegration Test and Error Correction Model. The results show that FDI, GDP per capita, service trade openness and exports of goods trade all have a significant positive impact on the China's service trade in export. Finally, it proposes policy-related suggestions to promote the development of service trade.
\end{abstract}

Keywords-service trade; diamond model; comparative advantage; cointegration test; error correction model

\section{INTRODUCTION}

With the continuous adjustment of the world economic structure and the acceleration of the world economic integration, the service trade has become the fastest field in the international trade, and its average annual growth rate has far exceeded that of the goods trade, which has been a new driving force for the world economic growth.

The development of service trade experienced a course from scratch to start, from small to large in China, and the import-export volume of service trade increased gradually, and its proportion in the world service trade went up as well. Especially after China's entry to the WTO in 2001, China's opening-up was further deepened and established closer relations with foreign countries, and China's service trade in services made a great progress and the import- export volume of service trade was on the rise year by year. From 2001 to 2010, the value of China's service trade increased from 71.9 billion dollars to 362.4 billion dollars, increased by over 5 times within 10 years, and more 80 times than 4.4 billion dollars in 1982. Up to 2013, China's value of import-export in service reached 539.64 billion dollars, increased at $14.7 \%$ compared to that of the previous year, the value of importexport volume in service accounted for $11.5 \%$ of China's total foreign trade, increased at $0.7 \%$ year on year.
Though the total value of service trade of the country increases remarkably, and the competitiveness is improved to some degree, traditional service trade sector grows up rapidly, the emerging service trade sector is booming, but there are a series of problems as the low level overall in service trade, unbalanced in regions and sectors and weak competitiveness. If the service industry can not be improved substantially, it will be a great loss to give the market share that we should own to others. Therefore, it is urgent to study the factors that affect the competitiveness of China's service trade and put forward corresponding countermeasures and suggestions.

\section{INTRODUCTION TO THEORIES CONCERNED}

Before the 1990s, many western scholars were devoted to studying the applicability of the principle of comparative advantages in service trade. R. Dick \& H. Dicke adopted the RCA method to analyze the data of 18 countries and found that the decisive roles of factor endowments were not significant. But Sapir (1982) firstly demonstrated the applicability of comparative advantages to the service trade, afterwards, Hindley \& Smith (1984), Hoekman \& Karsenty (1992) and Langhammer (1989) all found that the theory of comparative advantages were also applicable for the service trade, besides, the service trade patterns had close relations with factor endowments. In the time of new trade and economy, scholars have found that the scale economy is also an important factor to improve the international competitiveness of service trade. Krugman (1991), through analyzing the specialization of enterprise and the particular demands of consumers, thought that with the costs fixed, if enterprises could access larger market and own large production scales, their average costs could be reduced, therefore, the scale economy is the drive to the service trade. From the early 1990s to the beginning of the 21 st century, foreign scholars focused on some service sectors with great growth potential so as to study the international competitiveness of service trade. Fairborn et al. (2003) studied the factors that determined the trade of insurance service trade in the US trade and found that FDI had a significant influence to the value of insurance services trade, rather than the mutual substitution between trade and FDI as given in traditional trade theories. Fariborz (2005) et al also analyzed the trade of financial service trade in the US, and found that factor 
endowments, banking FDI, average capital income, scale of economy, trade concentration and openness were positively correlated with the trade in the financial service trade. During the period, Michael Porter combined the competitiveness and industrial elements for study and offered a famous National Diamond Model related to the industrial competitiveness, and study from the level of static, local comparative advantages was upgraded to the level of dynamic, global competitive advantages. In a word, after more than 40-year development, the theories of service trade abroad have been improved increasingly.

Compared with foreign scholars, China's scholars have fallen far behind in the study of service trade. Cheng Dazhong (2000), through comparing the relationship between the number of employment in the service sector and the export of service trade between US and China, found that in an open economy, the number of employment had a positive effect on the export revenue of service trade, which, however, will decrease due to the transformation of the service industry growth pattern from employment-based drive to the knowledge, technology and investment-based drive. Shi Zili and Xie Jingyi (2007) found that the service industry development level was the weakest factor for the influence. Zhang Yiyun. (2008) conducted multiple regression analysis on the relations between the value of export of China's service trade and GDP per capita, urbanization rate, FDI, openness, and human capital from 1991 to 2005 , and found that the urbanization rate had the highest contribution to the competitiveness of service trade. Lei Xingchang and Zhao Mingliang (2008) found that according to the educational background, if the quality of labor force increases by $1 \%$, the value of import-export of service trade will increase by $4.4085 \%$, which was much higher than that of goods trade, opening of service trade and the value FDI. Studies of Zheng Jichang, Xia Qing (2004), Wan Hongxian (2005), and Lu Sumei (2006) are all based on the Porter's theory of national competitive advantages, and combined the theory with service trade and expound the factors influencing China's service trade and raised countermeasures to improve the competitiveness of China's service trade.

Though there are many literatures about the factors influencing the competitiveness of China's service trade, yet most are based on statistical analysis indicators for measurement and are kept at the initial statistics and comparison of the high or low competitiveness, which are superficial, for few adopt the econometric methods, even used, only simple regression is used for conclusions. Accordingly, this article studies the factors that affect the competitiveness of China's service trade from the empirical aspect and selects explanatory variables as FDI, GDP per capita, openness of service trade, level of domestic service trade, level of domestic goods trade and takes exports of service trade as explained variables, creates a logarithm model, cointegration test and error correction mode to the long term and short-term factors influencing the export of service trade, finally, it raises suggestions applicable to improve the competitiveness of China's service trade.

\section{Modeling AND DATA TeSting}

Based on the diamond model theory, this article chooses main factors influencing the international competitiveness of China's service trade, establishes econometrics models and studies the impact of diverse factors on the international competitiveness of China's service trade, which provides theoretical basis for the work in the future.

\section{A. Diamond Model and Indicator Selection}

According to Michael Porter's theory national competitive advantages- Diamond Model, whether the industry in a country owns international competitiveness shall depend on four key factors namely factor conditions, demand conditions, related industries and supporting industry, enterprise strategic structure and competition, and two auxiliary factors, namely government and opportunities. Based on analysis of the status quo of international competitiveness of China's service trade, according to the diamond model, five related indicators are selected, namely, FDI, GDP per capita, openness of service trade market, development level of service industry and development level of goods trade.

FDI is a low-level production factor, for if the inflow of foreign investment to non-service industries will also indirectly affect the service industry, thus affecting the export of service. So it is replaced by the actual use of foreign investment in China, taken as FDI; GDP per capita represents per capita income of a country, reflecting the production and consumption of the whole economy and society, which is a symbol of domestic demand, taken as PGDP; The openness of service trade market is an important factor influencing the level of service in a country. Generally the openness of service trade market is positively related to the export capacity of the service industry. In this article it is placed with the ratio of total value of imports-exports of service trade in GDP, taken as OP; the development level of service industry in a country will have a direct impact on the ability of the country to provide services to the international market. The higher the development level of the service industry is, the stronger its capacity for service supply will be, and the more the service exports will be, this article adopts the ratio between the output value of the tertiary industry and GDP to measure, taken as SD The level of goods trade reflects the size of goods trade in China, and the growth of goods trade, to a large extent, will drive the development of related service industries, this article adopts the total value of exports of goods trade, taken as CT. The variables given above have a higher range so as to conduct a comprehensive study on factors influencing the international competitiveness of China's service trade.

The explained variable is a level of competitiveness of China's service trade, considering that the level of competitiveness is unable to weigh, this article adopts the total value of exports of China's service trade to represent the level of international competitiveness of service trade, taken as ST.

\section{B. Sampling and Data Selection}

All the data used in this article were within the period from 1985 to 2013, totaling 28 years. Among them, the actual use of FDI, GDP per capita and total value of export-import of 
service trade were extracted from China Statistical Yearbook and China Service Trade Statistics 2014 and so on; the GDP per capita, openness of service trade market were calculated as per the data from China Statistical Yearbook and the China National Bureau of Statistics and Ministry of Commerce.

Based on the logarithmetics, the data sequence is easy to access to stationary sequence, on the one hand, it may weaken the heteroskedasticity of the data the non-normal distribution of residual in the model; on the other hand, the economic data in logarithm are used for linear regression, the parameters ahead represent change rate of percentage $(d \ln x=d x / x)$, that is, elasticity, so the variables are in logarithm, that is, adopting $\operatorname{lnST}$, lnFDI, lnPGDP, lnOP, $\operatorname{lnSD}$ and $\operatorname{lnCT}$ instead, and then incorporate the new variable sequence to the model and analyze through the software Eviews 6.0.

\section{Modeling and Data Testing}

According to the independent variable indicators selected, this article creates an econometric model (natural logarithm used for the model) as follows:

$$
\begin{aligned}
& \ln S T=\beta_{0}+\beta_{1} \ln F D I+\beta_{2} \ln P G D P+\beta_{3} \ln O P \\
& +\beta_{4} \ln S D+\beta_{5} \ln C T+\varepsilon_{t}
\end{aligned}
$$

Where, $\beta_{0}, \beta_{1}, \beta_{2}, \beta_{3}, \beta_{4}$ and $\beta_{5}$ are parameters to be estimated, $\beta_{1}, \beta_{2}, \beta_{3}, \beta_{4}$ and $\beta_{5}$ are used to weigh the elasticity of the value of exports of service trade to FDI, GDP per capita, openness of service trade market, level of service trade development and value of exports of goods, $\beta_{0}$ is constant, ${ }^{\varepsilon_{t}}$ is stochastic disturbance

1) Variable stationarity test: For the data used in the model are time-series data, but most are non-stationary, if it is directly used for regression, it will be of a high possibility of "spurious regressions". In order to prevent the result, first of all, it needs to conduct stationarity tests on the variables, for this purpose, an ADF method is used to conduct stationarity tests on variables and differential sequences of their own. The results are shown as follows "Table I".

The ADF test results show that the variable LNST fails to pass the ADF test at the significance level of $1 \%$. The ADF statistics of variables $\operatorname{lnFDI}, \ln \mathrm{PGDP}, \operatorname{lnOP}, \ln \mathrm{SD}$ and $\operatorname{lnCT}$ are more than the critical values, failing to pass the stationarity tests either, which prove that all the variable sequences are non-stationary. After the first-order difference, the ADF test values of variables LNST, $\operatorname{lnFDI}, \ln$ PGDP, $\operatorname{lnOP}, \operatorname{lnSD}$ and $\operatorname{lnCT}$ at the significance level of $5 \%$ are less than the critical values, which prove that all variables have passed the ADF tests at the significant level of 5\% at least, and they are the first order single integral sequence I (1). It means that although the six variables vary, but the first-order difference of their logarithm is stationary, and it is applicable for cointegration tests.

\begin{tabular}{|c|c|c|c|c|c|}
\hline Variable & $\begin{array}{c}\text { ADF } \\
\text { Statistics }\end{array}$ & $\begin{array}{c}1 \% \\
\text { Critical } \\
\text { Value } \\
\end{array}$ & $\begin{array}{c}5 \% \\
\text { Critical } \\
\text { Value } \\
\end{array}$ & $\begin{array}{c}10 \% \\
\text { Critical } \\
\text { Value } \\
\end{array}$ & $\begin{array}{c}\text { Conclu } \\
\text { sion }\end{array}$ \\
\hline LNST & -4.361806 & -4.416345 & -3.622033 & -3.248592 & $\begin{array}{l}\text { Non- } \\
\text { stationa } \\
\text { ry }\end{array}$ \\
\hline$\triangle \mathrm{LNST}$ & -3.885516 & -4.440739 & -3.632896 & -3.254671 & $\begin{array}{l}\text { Station } \\
\text { ary }\end{array}$ \\
\hline LNFDI & -1.828855 & -4.323979 & -3.580623 & -3.225334 & $\begin{array}{l}\text { Non- } \\
\text { stationa } \\
\text { ry }\end{array}$ \\
\hline$\triangle \mathrm{LNFDI}$ & -4.097360 & -4.339330 & -3.587527 & $\begin{array}{c}- \\
3.229230\end{array}$ & $\begin{array}{l}\text { Station } \\
\text { ary }\end{array}$ \\
\hline $\begin{array}{l}\text { LNPGD } \\
\mathrm{P}\end{array}$ & -2.038851 & -4.416345 & -3.622033 & $\begin{array}{c}- \\
3.248592\end{array}$ & $\begin{array}{l}\text { Non- } \\
\text { stationa } \\
\text { ry }\end{array}$ \\
\hline $\begin{array}{l}\triangle \mathrm{LNPG} \\
\mathrm{DP}\end{array}$ & -3.638424 & -4.394309 & -3.612199 & $\begin{array}{c}- \\
3.243079\end{array}$ & $\begin{array}{l}\text { Station } \\
\text { ary }\end{array}$ \\
\hline LNOP & -1.175274 & -4.323979 & -3.580623 & $\begin{array}{c}- \\
3.225334\end{array}$ & $\begin{array}{l}\text { Non- } \\
\text { stationa } \\
\text { ry }\end{array}$ \\
\hline$\triangle \mathrm{LNOP}$ & -6.458260 & -4.339330 & -3.587527 & $\begin{array}{c}- \\
3.229230\end{array}$ & $\begin{array}{l}\text { Station } \\
\text { ary }\end{array}$ \\
\hline LNSD & -3.027792 & -4.339330 & -3.587527 & 3.229230 & $\begin{array}{l}\text { Non- } \\
\text { stationa } \\
\text { ry }\end{array}$ \\
\hline$\triangle \mathrm{LNSD}$ & -4.001238 & -4.339330 & -3.587527 & $\begin{array}{c}- \\
3.229230\end{array}$ & $\begin{array}{l}\text { Station } \\
\text { ary }\end{array}$ \\
\hline LNCT & -1.953570 & -4.323979 & -3.580623 & 3.225334 & $\begin{array}{l}\text { Non- } \\
\text { stationa } \\
\text { ry }\end{array}$ \\
\hline$\triangle \mathrm{LNCT}$ & -4.994092 & -4.339330 & -3.587527 & $\begin{array}{c}- \\
3.229230\end{array}$ & $\begin{array}{l}\text { Station } \\
\text { ary }\end{array}$ \\
\hline
\end{tabular}

TABLE I. UNIT ROOT TESTS OF VARIABLES

2) Cointegration tests: In order to clarify whether there is a cointegration relationship between the value of exports of service trade ST and the explanatory variables as FDI, PGDP, $\mathrm{OP}, \mathrm{SD}$ and CT, a regression is done on the original model, the stationarity of regression residuals is tested. The model is estimated through least squares with the result given as follows "Table II"

TABLE II. RESUlTS OF STATIC REGRESSION

\begin{tabular}{l|l|l|l|c}
\hline \multicolumn{1}{c|}{ Variable } & Coefficient & Std. Error & \multicolumn{1}{c|}{ t-Statistic } & Prob. \\
\hline C & -1.755013 & 0.895845 & -1.959059 & 0.0623 \\
\hline LNFDI & 0.194057 & 0.054067 & 3.589183 & 0.0016 \\
\hline LNPGDP & 0.053827 & 0.027673 & 1.945097 & 0.0641 \\
\hline LNOP & 0.161991 & 0.084698 & 1.912567 & 0.0683 \\
\hline LNSD & -0.146374 & 0.304891 & -0.480087 & 0.6357 \\
\hline LNCT & 0.782841 & 0.038810 & 20.17122 & 0.0000 \\
\hline R-squared & 0.998241 & & $\begin{array}{l}\text { Adjusted } \\
\text { squared }\end{array}$ & 0.997859 \\
\hline $\begin{array}{l}\text { S.E. } \\
\text { regression }\end{array}$ & 0.062950 & $\begin{array}{l}\text { Durbin-Watson } \\
\text { stat }\end{array}$ & 1.391345 \\
\hline F-statistic & 2610.574 & & Prob(F-statistic) & 0.000000 \\
\hline
\end{tabular}


The regression results show, the goodness of fit of the model is $99.79 \%$, indicating that the model fits well. The regression equation has passed F-test, it means that the explanatory variables have a significant effect on the explained ones. Meanwhile, it is found that the $\mathrm{P}$ value of variable LNSD is greater, failing to pass t-test, it means that this variable has no significant effects on the export of China's service trade, so it will be deleted out of the original mode.

Based on the original model, the variable LNSD is deleted for re-regression, the software output is given as follows $(\mathrm{t}$ statistics given in the brackets)

$\ln S T=-2.180628+0.19658 \ln F D I+0.053242 \ln P G D P+0.155207 \ln O P+0.769631 \ln C T$

$\begin{array}{llll}(-17.20820)(3.713177) & (1.957437)(1.889050)\end{array}$

(28.58210)

$$
R^{2}=0.998223 \text { modified } R^{2}=0.997927
$$

$$
\text { F statistics }=3371.253 \quad \mathrm{DW}=1.382889
$$

According to the regression results, the modified $R^{2}$ in the model is 0.997927 , indicating that the model fits better. All variables have passed $t$ tests, it means that the variables have a significant impact on the explained ones. Furthermore, the $\mathrm{ADF}$ cointegration test is used to test the residual sequence of the regression equation. The test results are given as follows:

TABLE III. TEST RESUlts OF RESIDUAL SEQUENCE ON THE BASIS OF $\mathrm{ADF}$

\begin{tabular}{c|c|c|c|c|c}
\hline $\begin{array}{c}\text { ADF } \\
\text { Value }\end{array}$ & $\begin{array}{c}\mathbf{1 \%} \\
\text { Critical } \\
\text { Value }\end{array}$ & $\begin{array}{c}\mathbf{5 \%} \\
\text { Critical } \\
\text { Value }\end{array}$ & $\begin{array}{c}\mathbf{1 0 \%} \\
\text { Critical } \\
\text { Value }\end{array}$ & $\begin{array}{c}\mathbf{P} \\
\text { Value }\end{array}$ & $\begin{array}{c}\text { Conc } \\
\text { lusion }\end{array}$ \\
\hline- & -2.650145 & -1.953381 & -1.609798 & 0.0002 & Stationary \\
\hline .128234 & & & & \\
\hline
\end{tabular}

The test results show, the ADF statistic value is -4.128234 , less than the critical value at the significance level of $5 \%$. Therefore, the original hypothesis can be rejected at a confidence level of $95 \%$, that is, the residual sequence has no unit root, which is stationary. Furthermore, it means that the exports of China's service trade have a cointegration relationship with FDI, PGDP, OP and CT, and there is a longterm balance between them. The coefficients of all indicators are positive, indicating that the indicators and the explained variables are positively correlated.

3) Create an error correction model (ECM): Due to the cointegration relationship between the variable LNST and LNFDI, LNPGDP, LNOP and LNCT, it means that there is a long-term balance between the value of exports of service trade and FDI, GDP per capita, openness of service trade and the value of exports of goods trade. In order to enhance the accuracy of the model, the error items in the cointegration regression can be regarded as a balance model, through creating an error correction model, the value of exports of service trade can be connected with the short term behaviors and long-term changes of other five variables. Therefore, an error correction model is created as follows

$\Delta L N S T_{t}=\alpha_{0}+\alpha_{1} \Delta L N F D I_{t}+\alpha_{2} \Delta L N P G D P_{t}+\alpha_{3} \Delta L N O P_{t}+\alpha_{4} \Delta L N C T_{t}+\alpha_{5} E C M_{t-1}+\varepsilon_{t}$
According to the ECM model given above, the sequence is estimated through least squares with the result given as follows:

TABLE IV. Statistics Results of ERror CORRECTION MODEL Tests

\begin{tabular}{l|l|l|l|c}
\hline \multicolumn{1}{c|}{ Variable } & Coefficient & Std. Error & \multicolumn{1}{c}{ t-Statistic } & Prob. \\
\hline $\mathrm{C}$ & 0.044714 & 0.020451 & 2.186392 & 0.0408 \\
\hline $\mathrm{D}(\mathrm{LNFDI})$ & 0.143896 & 0.057324 & 2.510224 & 0.0208 \\
\hline $\mathrm{D}(\mathrm{LNPGDP})$ & 0.037802 & 0.017394 & 2.173294 & 0.0419 \\
\hline $\mathrm{D}(\mathrm{LNOP})$ & 0.278138 & 0.090054 & 3.088582 & 0.0058 \\
\hline $\mathrm{D}(\mathrm{LNCT})$ & 0.594872 & 0.105496 & 5.638819 & 0.0000 \\
\hline $\mathrm{D}(\mathrm{LNST}(-1))$ & -0.133687 & 0.093298 & -1.432901 & 0.1673 \\
\hline ECM & -0.590394 & 0.197334 & -2.991844 & 0.0072 \\
\hline R-squared & 0.868109 & & $\begin{array}{l}\text { Adjusted } \\
\text { squared }\end{array}$ & 0.828542 \\
\hline $\begin{array}{l}\text { S.E. } \\
\text { regression }\end{array}$ & 0.046623 & & $\begin{array}{l}\text { Durbin-Watson } \\
\text { stat }\end{array}$ & 1.599534 \\
\hline F-statistic & 21.94006 & & Prob(F-statistic) & 0.000000 \\
\hline
\end{tabular}

Test results of the error correction model show, FDI, GDP per capita, openness of service trade and value of exports of goods trade may deviate from the long-run balance level between them and the value of exports of service trade, if it occurs, the deviation for the growth of export of service trade will be corrected at a rate of 0.590394 . FDI, GDP per capita, openness of service trade and value of exports of goods trade are influencing the annual growth of value of exports of service trade at a rate of $0.143896,0.037802,0.278138$ and 0.594872 respectively. Among them, the short term fluctuation of the value of exports of goods trade has the most significant effect on the short-term change of service trade, while the influence of openness of service trade is almost the same as that of FDI, and the influence of GDP per capita is lower. It shows that to develop the service trade and strengthen the openness of service trade and FDI will play a crucial role in promoting the rapid and stable development of service trade.

\section{CONCLUSION AND SUGGESTIONS}

Seen from the above empirical results, we can see that the explanatory variables in the regression equation have explanatory power to the explained ones, so the establishment of the regression equation is reasonable. According to the estimation results, FDI, GDP per capita, openness of service trade and the value of export of goods trade have a positive impact on the exports of China's service trade. Among them, if FDI, GDP per capita, openness of service trade and the value of export of goods trade are increased by $1 \%$, the value of exports of China's service trade will increase by $0.2,0.05,0.16$, 0.77 respectively. Thus, the development level of China's goods trade has the greatest impact on the competitiveness of service trade, although the amount of FDI has certain influence on China's service trade, yet its contribution is far less than that of the exports goods trade, which reflects that the role of FDI in driving China's service trade has not been fully exerted. On the other hand, the role of GDP per capita and openness of service trade market in promoting the exports of China's 
service trade is unsharp. In the long run, there exits a longterm and stable relationship between the export of China's service trade and FDI, GDP per capita, openness of service trade market and the level of goods trade. The error correction model shows, the short-term fluctuation of goods trade has the greatest impact on the export capacity of service trade, and the mature goods trade will further promote the development of service trade. Therefore, it is necessary to full exert the role goods trade to drive the service so as to achieve a joint development.

First of all, actively guide the flow of foreign capital and improve the use efficiency. The FDI can not only improve the supply and export of service products, but also through achieve technology spillovers through various channels. First, it needs to adjust the structure of the service industry to make use of foreign capitals, accelerate the transfer of foreign investment to the service industry, especially to modern service industry with intensive capital and technologies. Second, it needs to break the monopoly and create a healthy market competition. Finally, it needs to guide the FDI to productive services so as to expand the employment. Using FDI to raise the technical level and management means of service enterprises in China and improve the international competitiveness of China's service industry and service trade fundamentally.

Second, regard the domestic demand for service industry, and actively guide residents to change consumption habits and optimize the consumption structure. Residents have a huge space and potentials for service consumption, relying on technological innovation, enterprises should focus on the development of service industry with technical contents and high added value, improve the service quality, change the concept of service, provide Chinese residents with diversified service products and high efficiency service, prompt the people to actively adjust consumption structure and habits of their own, increase the demand for service products, and take the domestic huge demand for services to active participation in international competition.

Third, reduce the service control, increase the openness of the service industry and upgrade the competitiveness of service trade. As a whole, the openness of China's service trade is low and in a narrow field, so China should expand the opening-up to of the service industry. On the one hand, intensify the openness of the service industry which is in a high monopoly at home, withdraw state-owned capitals to some degree to achieve the separation of governments and enterprises, meanwhile, according to the commitments to the entry of the WTO, more opening policies shall be established to grant the same treatments for domestic and foreign enterprises; on the other hand, encourage private capitals and even foreign capitals to access to the capital-intensive industries, stimulate the industrial upgrading and enhance the competitiveness of the service industry.

Fourth, accelerate the development of service trade and strengthen its linkage effect with goods trade. The goods trade is separated from the service trade in China, besides, the linkage effect is not obvious, and the development of service trade is far from that of goods trade. Therefore, it needs to explore and regard opportunities for the service trade hidden in the goods trade such as insurance, finance, consulting and other new services, make full use of the opportunities, change the ways of goods trade, constantly optimize the structure of goods trade, and rely on the goods trade to drive the service industry so as to enhance the overall competitiveness of China's of service trade.

\section{REFERENCES}

[1] R.Dick\&H.Dicke,Patterns of Trade in Knowledge[ M] .In H.Giersch (ed .) International Eocnomic Development and Resources Transfer, 1979, Tubingen :J.C.B .Mohr, p .346.

[2] A.Sapir, Trade in Services :Policy Issues for the Eighties Columbia [ J] .Journal of World Bank, 1982, (79).

[3] Hindley\&Smith, Comparative Advantage and Trade in Services [ J] .The World Economy, 1984, 7 (4):369 389.

[4] B.Hoekman \&G.Karsenty .Economic development and international transaction in services [ J] .Development Policy Review, 1992,(10):211 236.

[5] R.J.Langhammer .North - South trade in services: some empirical evidence [ M] .Services in World Economic Growth, 1989:211 322.

[6] Fariborz Moshirian, Donghui Li , Ah -Boon Sim .The Determinants Of Intra -Industry Trade In Insurance Services [ J] .The Journal of Risk and Insurance, 2003, 70 (2):269 287.

[7] Fariborz Moshirian, Donghui Li , Ah -Boon Sim.Intra -industry trade in financial services [ J] .Journal of International Money and Finance , $2005,(24): 1090 \sim 1107$.

[8] Shi Zili, Xie Jingyi, Analysis of Factors Influencing the Competitiveness of China's Service Trade and Countermeasures [J]. Research on Economics and Management 2007,(4):60 64

[9] Zhang Yiyun, Analysis of Factors Influencing the Competitiveness of China's Service Trade [J].China's Foreign Trade, 2008, (3):86 89.

[10] Lei Xingchang, Zhao Mingliang, Mathematical Analysis on Factors Influencing China's Service Trade $[\mathrm{J}]$. Journal of Shanghai Lixin University of Commerce, 2008,(4):85 89.

[11] Zhuang Huiming, Huang Jianzhong, The Evolution of Internationa Trade Theories: Dimension, Path and Logic, Journal of International Trade, Vol.11, 2008

[12] Yi Danhui, Data Analysis and Eviews Application [M].Version 2008, China Renmin University Press, 2012

[13] Zhou Jing, Lyu Jiyue, Empirical Analysis of Factors Influencing the Competitiveness of China's Tourism Service Trade [J]. Journal of International Trade, 2008,(4):71 75. 